\title{
GSSE
}

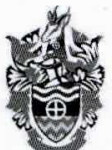

\section{Statistical evaluation of seismic event location accuracy by the South African National Seismograph Network over four decades}

\author{
I. Saunders \\ Council for Geoscience, Private Bag X112, Silverton, Pretoria South Africa \\ e-mail: ians@geoscience.org.za
}

\author{
A. Kijko \\ Natural Hazard Centre, University of Pretoria, Private Bag X20, Hatfield, South Africa \\ e-mail: andrzej.kijko@up.ac.za
}

\section{C.J.S. Fourie}

Environmental, Water and Earth Science Department, Faculty of Science, Tshwane University of Technology, Private Bag X460, Pretoria, South Africa

e-mail: fouriecjs@tut.ac.za

(c) 2016 March Geological Society of South Africa

\begin{abstract}
We analyzed the changes/improvements of seismic event detection and location accuracy of the South African National Seismograph Network over the last four decades. The effect of three regional velocity models on epicentral solutions was tested during the initial study. It is shown that the hypocentral depth considered during this study, viz. at $2 \mathrm{~km}$ for mining related events, and $5 \mathrm{~km}$ to $10 \mathrm{~km}$ for tectonic earthquakes, have a negligible effect on the error in epicentre location. Further, three detection distances were evaluated during this study, viz. 300,500 and $1000 \mathrm{~km}$. The location errors decreased significantly by increasing the detecting distance. This study highlights the importance of including $S$-phase arrival times to better constrain seismic event locations. This observation is of particular value for the 1970 to 1997 period, when only $P$-phases were considered during the location procedure. Lastly, it is shown how the errors in epicentre location decrease with an increase in the number and geographical distribution of seismic stations.
\end{abstract}

\section{Introduction}

The primary objective of a regional seismograph network is to record seismic signals within a limited geographic region of interest (Trnkoczy et al., 2002). Wave onset times are identified from the recorded signals after which epicentral/hypocentral coordinates of seismic events can be calculated, most often through the iterative least-squares procedure (e.g. Ge, 2003). It should be noted that in our working environment the term 'seismic event' encompasses induced seismic events, triggered seismic events and earthquakes with a tectonic origin.

The arrival times and coordinates of seismic event location are published in seismological catalogues. The spatial completeness of such catalogues can be ascribed to the detection capability of the network, which is a function of the sensitivity of the recording equipment station geometry (azimuthal distribution) an inadequate, or low number of observation stations in the region, and station availability (e.g. Husen and Hardebeck, 2010). A key factor in network capability with time is advances in technology leading to increased sensitivity (which also implies spatial completeness), and the inevitable geographic expansion of the network (e.g. Husen and Hardebeck, 2010, Hutton et al., 2010).

The accuracy of located events provided in the seismic catalogue depends on two kinds of errors: systematic and random. Systematic errors are introduced from incorrect station coordinates and an inexact velocity model where lateral heterogeneities are not considered leading to erroneous 

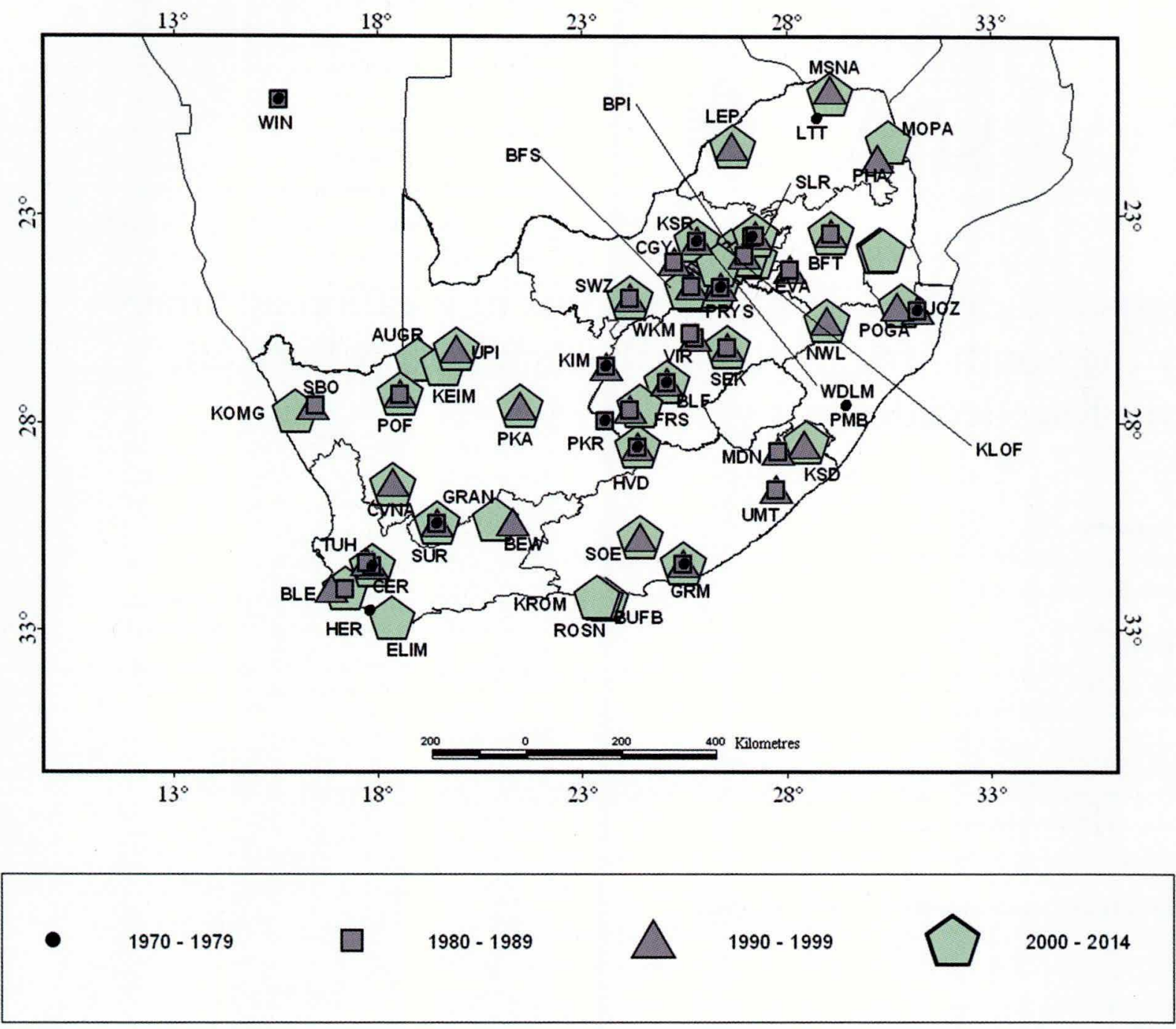

Figure 1. Geographic expansion of the South African National Seismograph Network (SANSN) over four decades from 1970 to 2014.

predicted arrival-time calculations (Billings et al. 1994; Douglas et al., 1997; Douglas et al., 2005). Random errors result from misidentification of phase-time arrivals in part due to analyst error, low signal-to-noise ratio and equipment unable to resolve the dominant frequency of expected phases (Pavlis, 1986).

The South African National Seismograph Network (SANSN) is a regional network principally developed to monitor the seismicity of South Africa. The area is approximately bounded by $22^{\circ} \mathrm{S} 11^{\circ} \mathrm{E}$ and $36^{\circ} \mathrm{S} 36^{\circ} \mathrm{E}$ (Figure 1). The SANSN was developed from 1971 onward (Fernández et al., 1991; Wright and Fernández, 2003 and Saunders et al., 2008) following a magnitude 6.3 earthquake in the Ceres area on 29 September 1969 (Green and Bloch, 1971). The origin of the SANSN is a consolidation of stations previously operated by various institutions (Wright and Fernández, 2003) under the auspices of the South African Geological Survey (now the Council for Geoscience), coupled with the installation of additional stations. The expansion of the SANSN during the period 1971 to 2014 is provided as Figure 1.

This study evaluates the statistical regional location capability (Kijko, 1977a and 1977b; Kijko, 1978; Kijko and
Sellevoll, 1982; Kijko and Sciocatti, 1995) of the SANSN through relating the documented seismic sources of South Africa to the geographical evolution of the SANSN over a period of more than 40 years. Further, the potential significance of omitting S-phase arrivals prior to the implementation of the HYPOCENTER software (Lienert and Havskov, 1995) during 1997 is also investigated.

\section{Seismicity}

From a tectonic perspective, South Africa is an intraplate region with a low level of tectonic seismicity considering the criteria of Johnston et al. (1994) that differentiate Stable Continental Regions (SCRs) from Active Plate Boundaries. The definition of SCRs (Johnston et al., 1994) encompasses continental regions where the continental crust is mostly unchanged through recent plate induced tectonism, and includes areas that had been tectonically inactive from the Mesozoic (252 to $66 \mathrm{Ma}$ ) to the Cenozoic Era ( $66 \mathrm{Ma}$ to present). It is noted, however, that South Africa has been subjected to vertical epeirogenic uplift (180 to $40 \mathrm{Ma}$ ) that is linked to vertical dynamic forces in the upper mantle 
(e.g. Nyblade and Sleep, 2003; Braun et al. 2014). In addition, Viola et al., (2012), demonstrated long lasting brittle fracture on pre-existing structures over a $\sim 500 \mathrm{Ma}$ time period along the western coast of South Africa.

Du Plessis (1996) confirmed the diffuse nature of South African seismicity in the context of SCRs and defined six seismic zones from a collective interpretation of geologic, geomorphologic, geophysical and seismological data. Eleven tectonic origin seismic clusters in southern Africa were additionally identified. These seismic clusters emphasize areas within seismic zones where anomalous concentrations of tectonically induced seismic activity have been observed over time from historical (Brandt et al., 2005) and/or instrumental records. An additional cluster, Leeu-Gamka (Matuludi, 2013), was recognized from observations after 2006 when continuous digital waveform data transmission was enabled for the SANSN (Saunders et al., 2008). Similarly, spatio-temporal seismic swarms (e.g. Yamashita, 1998) are not uncommon in South Africa, as observed by Fernández and Guzmán (1979). Two earthquake swarms, viz. Sutherland and an unnamed swarm on the Lesotho/South African border (coinciding with the south-eastern sector of the Eastern Lesotho cluster of Du Plessis, 1996) were identified by Fernández and Guzmán
(1979). Another seismic swarm manifested in the Augrabies area (Akromah, 2013) during the 2006 to 2014 period and comprises $\sim 1050$ earthquakes with magnitudes ranging from $0.1 \leq \mathrm{M}_{\mathrm{L}} \leq 5.4$. This swarm mostly coincides with the northern part of the Grootvloer cluster (Northern Province of South Africa) postulated by Du Plessis (1996). The extent of seismic zones (Du Plessis, 1996), tectonic clusters (Du Plessis, 1996 and Matuludi, 2013), areas/zones of induced seismicity in the gold mining region (e.g. Singh, 2009) and seismic swarms (Fernández and Guzmán, 1979 and Akromah, 2013), together with the position of prominent sources of explosions associated with opencast mines identified from the South African Mineral Deposits Database (SAMINDABA, 2014), is shown as Figure 2.

Having highlighted the disseminated nature of South African seismicity and demarcated the geographic extent of seismic clusters/swarms and other prominent sources of seismicity in southern Africa (Figure 2), it would be reasonable to presuppose that the newly established SANSN would have a representative station distribution within the defined study area. Contradictory to this assumption is a unique aspect of South African seismicity. That is, a major segment of recorded seismicity in South Africa is attributed to mining related

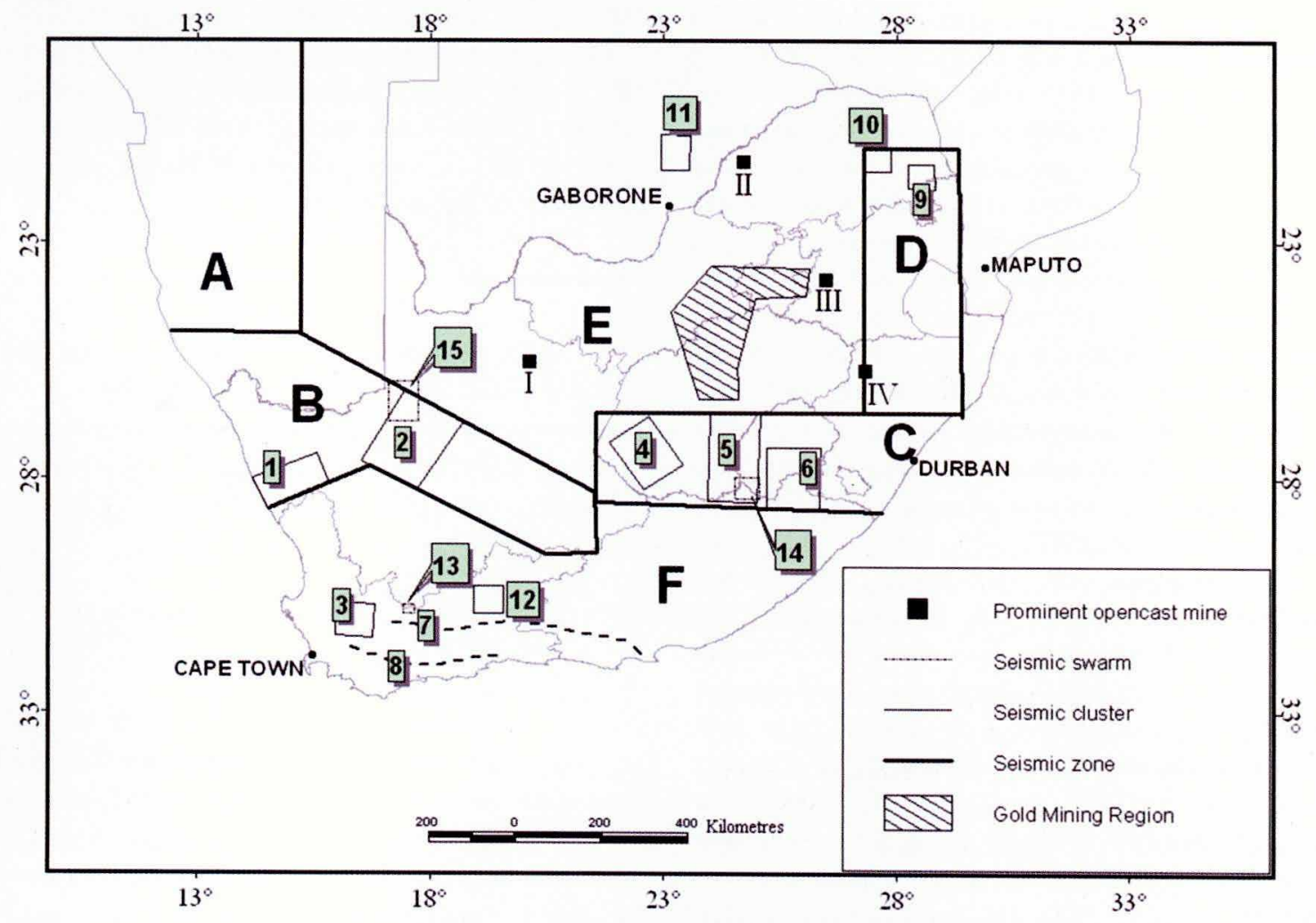

Figure 2. Seismic zones defined by Du Plessis (1996) are shown with a thick outline: (A) Namibia; (B) Karoo/Namaqualand; (C) Free State/Lesotho; (D) Northern Natal/Swaziland/Mpumalanga Lowveld; (E) Central South African Low and (F) Cape Low. Seismic clusters (polygons with thin borders) (Du Plessis (1996) are numerically indicated as: 1, Springbok/Kamieskroon; 2, Grootvloer; 3, Ceres; 4, Koffiefontein; 5, Eastern Lesotho; 6, Matatiele; 7, Kango-Baviaanskloof fault; 8, Worcester fault; 9, Phalaborwa; 10, Tzaneen, 11, Lephepe and 12, Leeu-Gamka (Matuludi, 2013). The polygons with stippled outlines define the extent of the Sutherland swarm 13, (Fernandez and Guzmán, 1979), Lesotho-South African border swarm 14, (Fernández and Guzmán, 1979) and the Augrabies swarm 15, (Akromah, 2013). The hatched polygon defines the gold mining region (Singh et al., 2009). The Roman numerals on the map define prominent opencast mines where explosions are prominently recorded (I-Sishen/Kalahari mines, II-Grootegeluk mines, III-Witbank/Highveld mines and IV-Ermelo/Klip River mines. 
earthquakes. More than $90 \%$ of seismic events located in South Africa originate in the deep gold mining areas of the Wits basin (e.g. Wood, 1913; Gane, 1946; McGarr, 1976; Shapira et al., 1987; Kijko, 1997; Singh et al., 2009 and others). This distinctive source of seismicity dictates a concentration of SANSN stations focused around the gold mining areas (Free State and Gauteng Provinces). This statement is substantiated by Shapira et al. (1987) who noted that the detection capabilities of the SANSN favors induced seismicity over regional tectonic seismicity.

\section{Earthquake location}

The iterative least-squares procedure was mostly applied during seismic event location following the inception of the SANSN. Fernández (1973) and Guzmán (1977; 1978) provide coordinates of epicentres of seismic events and their local magnitudes up to June 1977, when the event locations were determined from S-P arrival times. Thereafter, the spacedomain method (Lomnitz, 1977) was introduced during routine data analysis. The space-domain method considers distance residuals rather than travel time residuals by taking into account the initial hypocentral estimate nearest the closest observation station, and then, through iterative corrections, the seismic event latitude, longitude, depth and origin time are estimated. The space-domain procedure of Lomnitz (1977) is computationally simple and was thus coded as LOCAT and routinely used by the SANSN (Guzmán, 1978; Fernández, 1987). The LOCAT code exclusively considered P-phase arrival times to derive epicentral solutions recorded at three or more of the SANSN stations. A successive version of LOCAT, LOCATF (Fernández, 1987; 1991; 1996), limited epicentral solutions to a minimum of four observation stations and, additionally, included S-phase arrivals in the epicentral solution and further expanded the use of relative phase arrival times where the absolute arrival time was uncertain (Fernández, 1987; 1991; 1996). However, we were unable to ascertain credible evidence that the latter options of LOCATF had been implemented during routine location prior to its termination during the first quarter of 1997

Notably, limitations on hypocentral depths were introduced with the inception of the LOCAT location code. This was deemed necessary since hypocentral depths determined with a sparsely populated regional seismograph network are highly inaccurate (e.g. Lay and Wallace, 1995; Bormann, 2002; Havskov and Ottemöller, 2010). Therefore hypocentres associated with mining related events in the Witwatersrand Basin were fixed to $2 \mathrm{~km}$, which was considered to be the average depth of gold mining operations in South Africa (Guzmán, 1978). Also, focal depths of tectonic earthquakes were fixed at either 5 or $10 \mathrm{~km}$, depending on which solution converged best during the location procedure (Guzmán, 1978).

Klose and Seeber (2007) indicate a strong bimodal depth distribution in the underlying crust of SCRs. Consequently, the hypocentral distribution of tectonic events in SCRs is either confined to the upper crust ( 0 to $10 \mathrm{~km}$ ) and/or the lower crust ( 20 to $35 \mathrm{~km}$ ) with the 10 to $20 \mathrm{~km}$ interval being mostly aseismic. This was confirmed by Brandt (2014) who observed that earthquake activity in South Africa is confined to the upper one third of the crust ( 0 to $10 \mathrm{~km}$ depth).

The SEISAN earthquake analysis software (Ottemöller et al., 2012) was implemented during routine analysis for the SANSN from March 1997 (Brandt, 1997) following its successful implementation to monitor reservoir induced seismicity in the Kingdom of Lesotho on behalf of the Lesotho Highland Development Authority (Saunders, 1996). The HYPOCENTER algorithm (Lienert and Havskov, 1995), which uses a damped least-squares procedure to iteratively minimize travel time residuals, superseded the LOCATF code. More significantly, the HYPOCENTER software (Lienert and Havskov, 1995) considers arrival times of both longitudinal (P) and transverse (S) waves in the epicentral solution as opposed to LOCAT, which only considered P-wave travel times. Gomberg et al. (1990) demonstrated the significance in constraining hypocentral solutions considering P-phase and S-phase arrival times using the iterative least-squares procedure. It is therefore postulated that a notable improvement in epicentral solutions (considering hypocentre depth $z_{0}$ is fixed during the location process) would be attained using the HYPOCENTER code (Lienert and Havskov, 1995) for earthquakes located prior to its implementation (Brandt, 1997).

Significant advances to refine the 1D velocity model of South Africa resulted from the Kaapvaal Craton experiment (e.g. Carlson et al., 1996). The three layered earth model of Wright et al. (2002) replaced the two layered velocity model of Gane et al. (1956) during September 2006 (Saunders and Roblin, 2008). An investigation was undertaken by Midzi et al. (2010) to further refine the 1D velocity model for South Africa. The velocity models considered during this study are presented in Figure 3.

\section{Methodology}

We consider a statistical model for assessing the accuracy of seismic event location as described by Kijko (1977a) and Rabinowitz and Steinberg (2000). It is shown that the accuracy of seismic event location by a seismic network can be described by the confidence - ellipsoid:

$$
(\theta-\hat{\theta})^{T} M(\theta-\hat{\theta}) \leq \mathrm{const}
$$

where the vector of seismic event focal parameters $\theta=\left(\mathrm{x}_{0}, \mathrm{y}_{0}, \mathrm{z}_{0}, \mathrm{t}_{0}\right),\left(\mathrm{x}_{0}, \mathrm{y}_{0}, \mathrm{z}_{0}\right)$ denotes coordinates of the hypocentre and $t_{0}$ the origin time. Vector $\hat{\theta}$ is the least squares estimate of $\theta$. It is shown by Gibowicz and Kijko (1994) that inversion of matrix $\mathrm{M}$ is proportional to the variance-covariance matrix of seismic event parameters $\hat{\theta}$, where $\mathrm{M}=\mathrm{A}^{\mathrm{T}} \mathrm{A}$, and $\mathrm{A}$ is the (nx4) matrix of partial derivatives of $n$ arrival times with respect to $\theta$ evaluated at $\hat{\theta}$. The value of const is $4 \mathrm{~s}^{2} \mathrm{~F}_{\mathrm{w}}, 4, \mathrm{n}-4$, assuming that the travel time residuals $\left(\mathrm{s}^{2}\right)$ are normally distributed. $\mathrm{F}_{\mathrm{w},}, 4, \mathrm{n}-4$ is an F-statistic with 4 and $\mathrm{n}-4$ degrees of freedom for the critical level of $w$ (Flinn, 1965). The confidence ellipsoid is controlled by matrix M (e.g. Steinberg et al., 1995) and the volume of the confidence ellipsoid is proportional to $\operatorname{det}(M)^{1 / 4}$. The exponent $1 / 4$ relates to the four parameters $x_{0}, y_{0}$, $z_{0}$ and $t_{0}$. Therefore reduction of focal parameter errors can be 


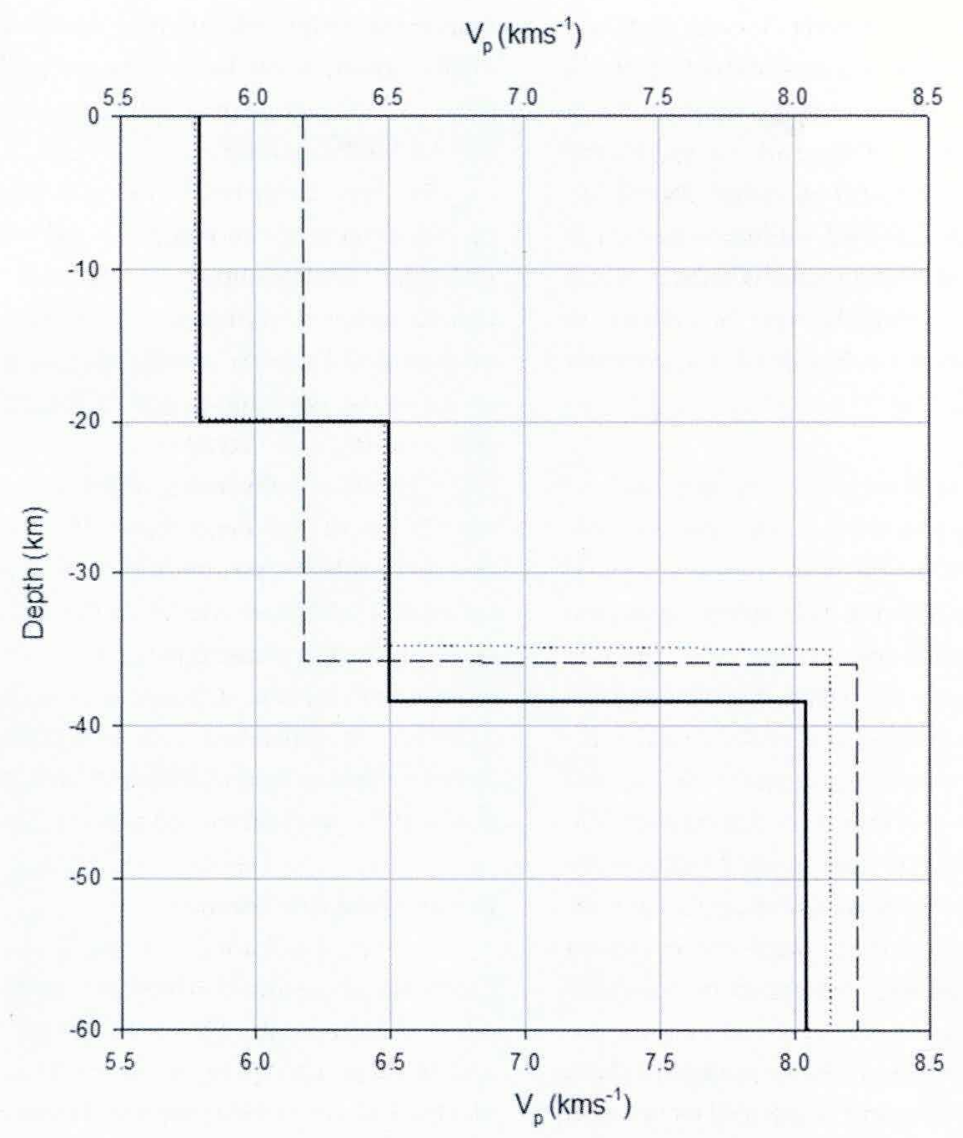

Figure 3. Velocity models considered during this study. The continuous line relates to the velocity model of Wright et al. (2002), the broken line defines the velocity model of Gane et al. (1956) and the dotted line the VM1 model of Midzi et al. (2010).

achieved by such spatial configuration of a seismic network which maximizes $\operatorname{det}(\mathrm{M})$.

However, the procedure of maximizing $\operatorname{det}(\mathrm{M})$ described above applies to a single source (event) only. Since multiple seismic sources with respect to station configuration will be applied during this study, the criteria for multiple sources (Kijko, 1977a and 1977b) were used by extending the solution by a discrete grid of $j$ point seismic sources:

$$
\sum_{l}^{j} w_{j}\left[\operatorname{det}\left(M_{j}\right)\right]
$$

where coefficients $w_{j}$ determine the 'importance' (level of seismicity) of a particular area.

We assume that stations comprising the SANSN operated at maximum capacity, that is, without interruption of data transmission during the period of review. Also, every observation at each observation station is allocated equal weight in the solution (Box and Draper, 1975). It is further assumed that phase identification errors and inaccuracies in the velocity model are normally distributed (Rabinowitz and Steinberg, 2000).

Three velocity models were considered as input: the Gane et al. (1956); Wright et al. (2002), and the VM1 model of Midzi et al. (2010). See Figure 3 for a comparison between the respective velocity models. Saunders et al. (2006) indicated an improvement in location using the Wright et al. (2002) model in comparison with the Gane et al. (1956) model with phase data recorded by the SANSN during the period 2000 to 2001 . As mentioned before, an alternative velocity model for South Africa was investigated by Midzi et al. (2010); however, the resultant model did not notably improve the Wright (2002) model (Figure 3). The effect of different velocity models is equally considered with the network distribution of 1970 coupled with an earthquake depth centred at $5 \mathrm{~km}$ in the detection range 300,500 and $1000 \mathrm{~km}$. In addition, a further two scenarios were considered; allowing only P-phase arrivals in the solution and inverting for both P- and S-phase arrival times.

Another consideration in our analysis is the selection of hypocentral depth distribution in the study area. Brandt (2014) modeled earthquake depths using regional depth phases $\left(\mathrm{sP}_{\mathrm{n}}, \mathrm{PmP}, \mathrm{sPmP}\right.$ and $\left.\mathrm{SmP}\right)$, thereby indicating tectonic earthquakes considered during his study were limited to the upper crust ( 0 to $10 \mathrm{~km}$ ) with average depths of $6.9 \mathrm{~km}$ $(\sigma \pm 2.3)$. Matuludi (2013) also determined shallow earthquake depths restricted to the $\sim 5 \leq \mathrm{D} \leq 10 \mathrm{~km}$ depth range during a study of the Leeu-Gamka cluster. However, Smit et al. (2015) determined that microseismicity in the Ceres cluster occurs at depths up to $5 \mathrm{~km}$ whilst hypocentres in the Tulbagh cluster ranged from 8 to $15 \mathrm{~km}$.

Brandt (2014) determined the depths of mining related events at $0 \mathrm{~km} \leq \mathrm{D} \leq 7 \mathrm{~km}$. The hypocentral depth of mining events is doubtful since Brandt (2014) determined the average 
depths of these earthquakes at $3 \mathrm{~km}$ with a large standard deviation $(\sigma \pm 3.9)$. It is noted that the goldmines in South Africa have reached depths of up to $4 \mathrm{~km}$ below surface. Therefore we considered the depth of operational goldmines between surface and $4 \mathrm{~km}$ with an average depth of $\sim 2 \mathrm{~km}$ below surface. Further, Goldbach (2009) indicates that fluid induced seismicity may have a significant influence when abandoned mines flood. This phenomenon is related to alteration of the ambient stress state through fluid pressure acting on the fault surface which may in turn trigger larger and potentially deeper earthquakes.

Three depth scenarios were considered during this study to account for events located in mining areas $(2 \mathrm{~km})$ and tectonic origin earthquakes $(5$ and $10 \mathrm{~km})$.

The penultimate consideration in modeling concerns the sensitivity of instrumentation comprising the SANSN. The specific details of instruments deployed during the 1970 to 2014 period are beyond the scope of this study.

In summary, the SANSN consisted principally of vertical component short-period analogue instruments during the 1970 to 1989 period. It should be noted that four stations were equipped with World-Wide Standard Seismographic Network instruments comprising short-period and long-period seismometers. Broadly, the magnification settings during 1970 to 1989 ranged from $6 \mathrm{~K}$ to $50 \mathrm{~K}$ for short-period instruments and 750 to $1.5 \mathrm{~K}$ for long-period sensors. Digital stations (16 bit digitizers with short-period sensors and triggered waveforms sampled at $50 \mathrm{~Hz}$ ) were introduced during 1991 (Fernández et al., 1991) and operated either in tandem with analogue instruments or as separate stations. It should be mentioned that the SANSN remained mostly analogue up to 1999 , consisting of short-period analogue instruments with magnification at either $25 \mathrm{~K}$ or $50 \mathrm{~K}$. A major upgrade of the SANSN was undertaken during 2000, when digital instruments replaced analogue instruments with standard short-period $(1.0 \mathrm{sec})$, extended short-period $(30 \mathrm{sec})$ or broadband sensors $(100 \mathrm{sec} / 120 \mathrm{sec})$ (Saunders et al., 2008). A further upgrade during 2005 replaced existing digitizers with mostly 24-bit digitizers (Saunders et al. 2008). Thus, a moderate estimate of detection thresholds, based on the expected sensitivity of the SANSN is $300 \mathrm{~km}$, $500 \mathrm{~km}$ and $1000 \mathrm{~km}$.

The final consideration is two-fold; firstly the significance of including S-phase arrivals in the location and secondly, the expected reading error of $\mathrm{P}$ - and S-phases. We therefore considered several distance threshold scenarios and excluded or included S-phase arrivals during the 1970 to 1999 period (prior to the implementation of the HYPOCENTER software in 1997) during calculations.

A $1.0 \mathrm{sec}$ reading error of P-phase arrival times was applied since P-phase arrivals in South Africa are generally observed as emergent rather than impulsive; this phenomenon is ascribed by Brandt and Saunders (2011) as brittle fracture in the upper crust producing these emergent P-waves. A more conservative estimate of $2.0 \mathrm{sec}$ in reading error was allowed for S-phase readings since the onset of this phase is superposed by the P-wave coda coupled with possible anisotropy (e.g. Graham et al., 1991) and converted phases (Diehl et al., 2011).

\section{Results and discussion}

Examples of results obtained during this study considering the effect of velocity models (Gane et al., 1956; Wright et al., 2002 and Midzi et al., 2010), hypocentral depth, detection distance, phases and network layout are shown in Table 1 and presented as Figures 4 to 8 .

Figure 4 (a to c) illustrate the analysis of the three velocity models considered during this study. It is evident that the errors in origin time and epicentre locations are similar irrespective of the velocity model used. We selected the Wright et al. (2002) model for the remainder of the study since it is the velocity model used during routine analysis of SANSN data (Saunders et al., 2006; Saunders and Roblin, 2008) after 2007. The Gane et al. (1956) model was used during routine analysis before 2007

Table 1. Examples of results obtained during this study.

\begin{tabular}{|c|c|c|c|c|c|c|}
\hline $\begin{array}{l}\text { Figure } \\
\text { No. }\end{array}$ & $\begin{array}{l}\text { Period } \\
\text { (Years) }\end{array}$ & $\begin{array}{c}\text { Velocity } \\
\text { model used }\end{array}$ & $\begin{array}{c}\text { Hypocentral } \\
\text { depth } \\
(\mathrm{km})\end{array}$ & Phases & $\begin{array}{c}\text { Detection } \\
\text { distance } \\
(\mathbf{k m})\end{array}$ & $\begin{array}{l}\text { Parameter } \\
\text { investigated }\end{array}$ \\
\hline 4(a) & 1970 to 1979 & Gane et al. (1956) & 5 & $P$ and $S$ & 1000 & Velocity model \\
\hline 4(b) & 1970 to 1979 & Wright et al. (2002) & 5 & $P$ and $S$ & 1000 & Velocity model \\
\hline $4(c)$ & 1970 to 1979 & Midzi et al. (2010) & 5 & $P$ and $S$ & 1000 & Velocity model \\
\hline $5(a)$ & 1970 to 1979 & Wright et al. (2002) & 2 & $P$ & 1000 & Hypocentral Depth \\
\hline 5(b) & 1970 to 1979 & Wright et al. (2002) & 5 & $P$ & 1000 & Hypocentral Depth \\
\hline $5(c)$ & 1970 to 1979 & Wright et al. (2002) & 10 & $P$ & 1000 & Hypocentral Depth \\
\hline $6(a)$ & 1970 to 1979 & Wright et al. (2002) & 5 & $P$ & 300 & Phases ( $P$-phase) and Detection Threshold \\
\hline 6(b) & 1970 to 1979 & Wright et al. (2002) & 5 & $P$ & 500 & Phases ( $P$-phase) and Detection Threshold \\
\hline $6(c)$ & 1970 to 1979 & Wright et al. (2002) & 5 & $P$ & 1000 & Phases ( $P$-phase) and Detection Threshold \\
\hline $7(\mathrm{a})$ & 1970 to 1979 & Wright et al. (2002) & 5 & $P$ and $S$ & 300 & Phases ( $P$ - and $S$-phase) and Detection Threshold \\
\hline 7 (b) & 1970 to 1979 & Wright et al. (2002) & 5 & $P$ and $S$ & 500 & Phases ( $P$ - and $S$-phase) and Detection Threshold \\
\hline $7(\mathrm{c})$ & 1970 to 1979 & Wright et al. (2002) & 5 & $P$ and $S$ & 1000 & Phases ( $P$ - and $S$-phase) and Detection Threshold \\
\hline $8(\mathrm{a})$ & 1970 to 1979 & Wright et al. (2002) & 5 & $P$ and $S$ & 1000 & Network Layout \\
\hline 8(b) & 1980 to 1989 & Wright et al. (2002) & 5 & $P$ and $S$ & 1000 & Network Layout \\
\hline $8(c)$ & 1990 to 1999 & Wright et al. (2002) & 5 & $P$ and $S$ & 1000 & Network Layout \\
\hline $8(d)$ & 2000 to 2014 & Wright et al. (2002) & 5 & $P$ and $S$ & 1000 & Network Layout \\
\hline
\end{tabular}




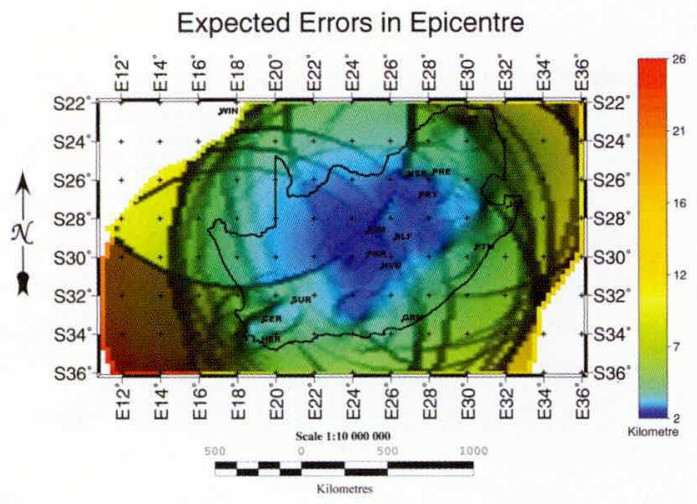

Expected Errors in Origin Time

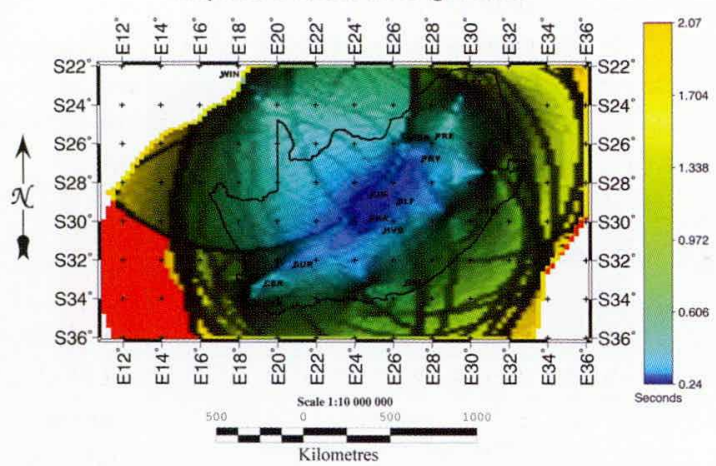

a
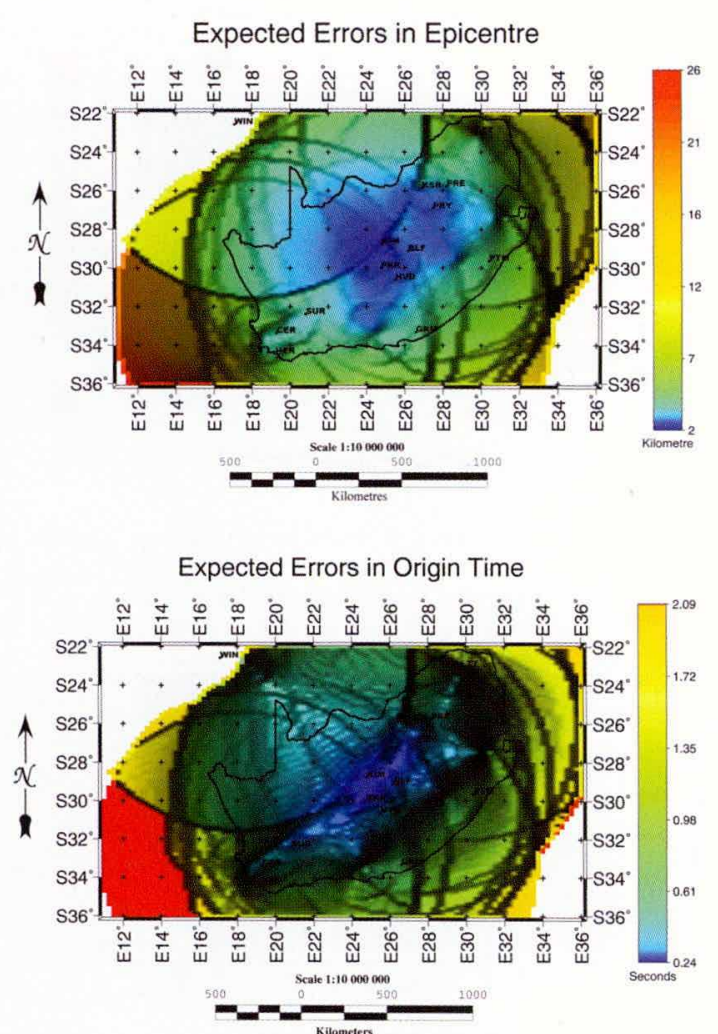

b

Expected Errors in Epicentre
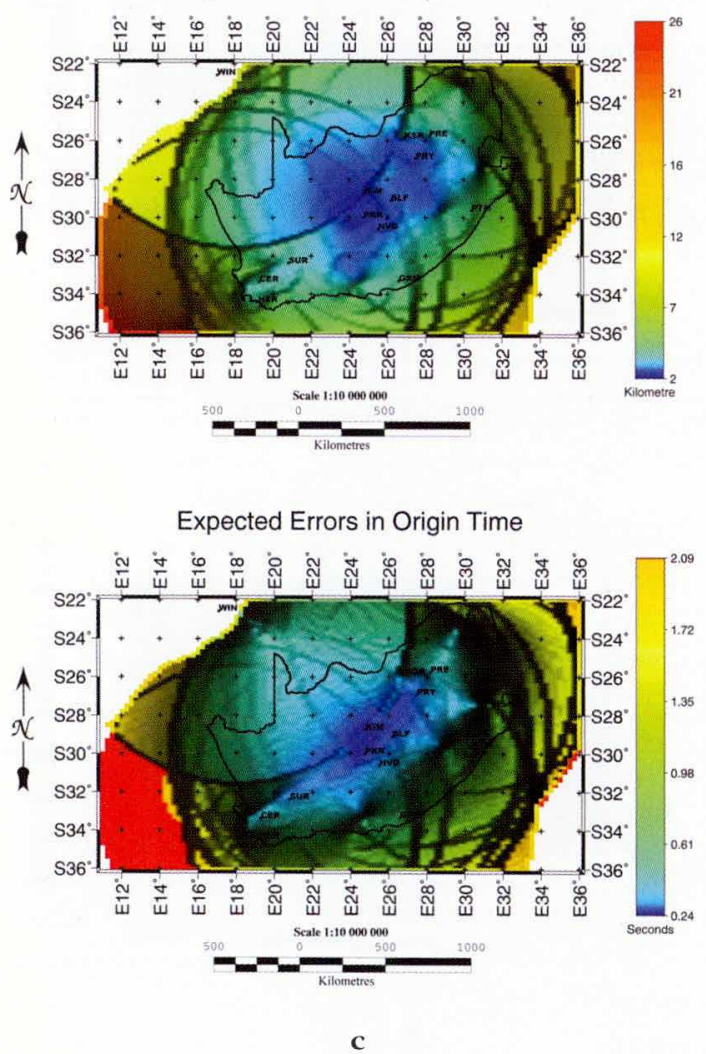

Figure 4. Detection thresholds obtained with: (a) the Gane et al. (1956) velocity model, (b) the Wright et al. (2002) velocity model and, (c) the Midzi et al. (2010) velocity model. The calculations were determined with the 1970 station configuration at a detection distance of $1000 \mathrm{~km}$ considering both P-and S-wave arrival times and a hypocentre depth of $5 \mathrm{~km}$. 

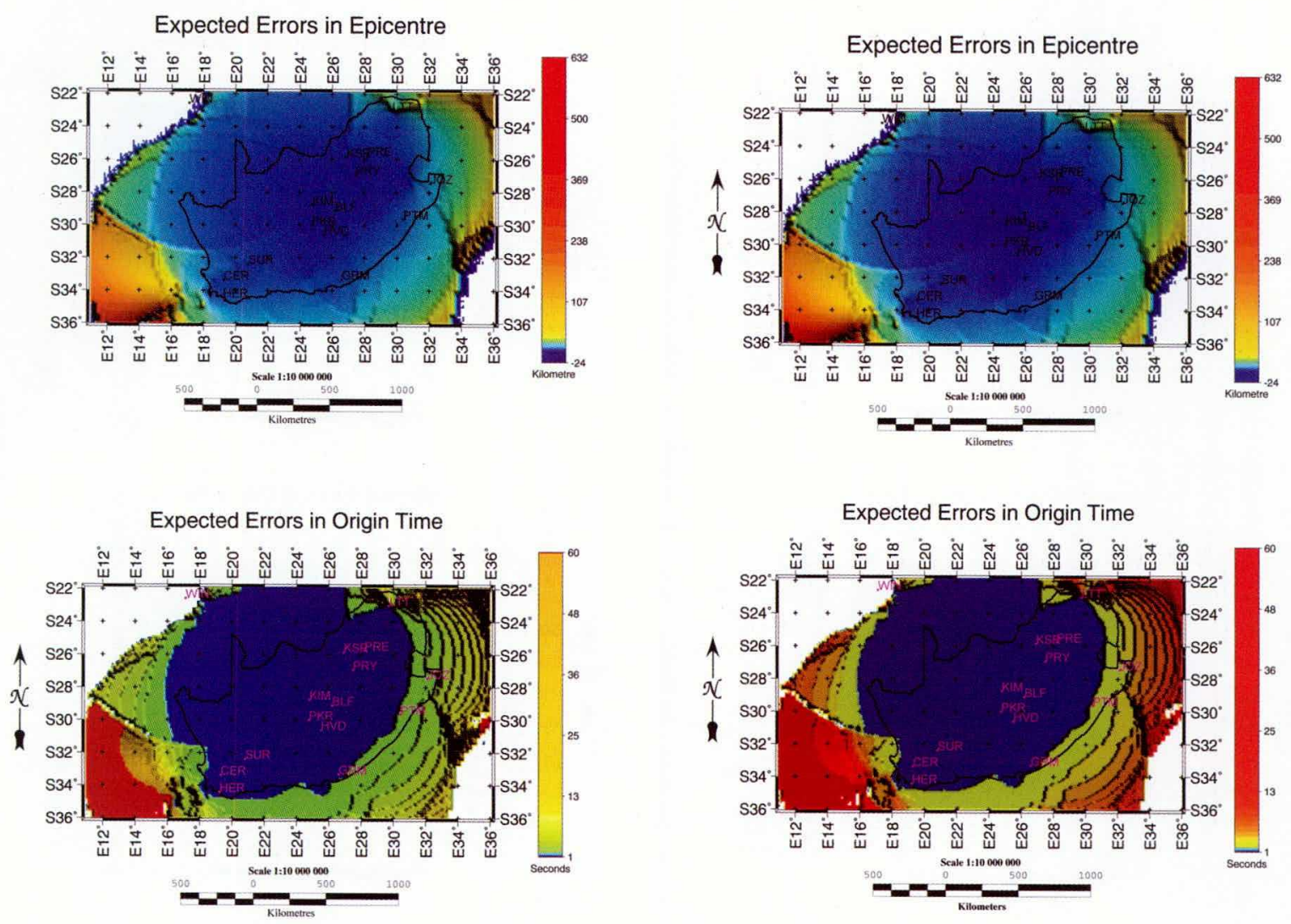

a

b

Expected Errors in Epicentre

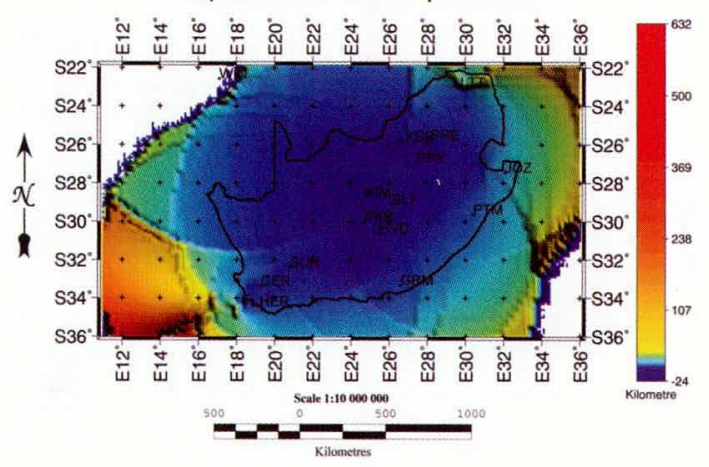

Expected Errors in Origin Time

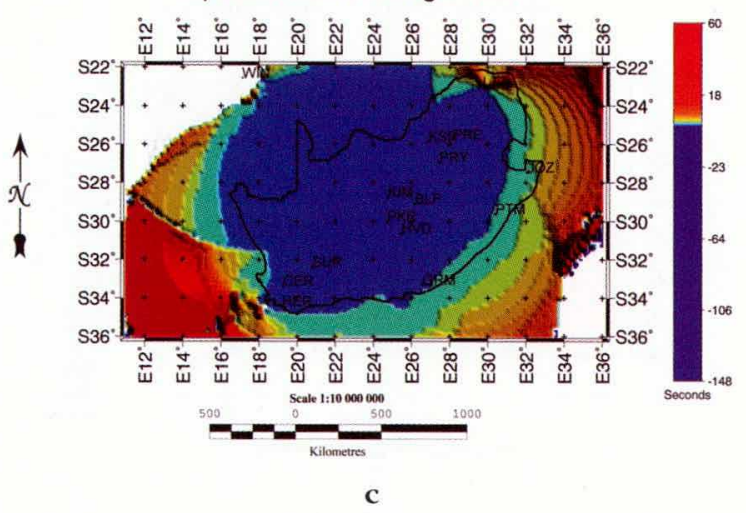

Figure 5. Detection thresholds obtained with the Wright et al. (2002) velocity model and: (a) hypocentral depth of 2 km, (b) hypocentral depth of $5 \mathrm{~km}$ and, (c) bypocentral depth of $10 \mathrm{~km}$. The calculations were determined with the 1970 station configuration at a detection distance of $1000 \mathrm{~km}$ considering P-wave arrival times. 

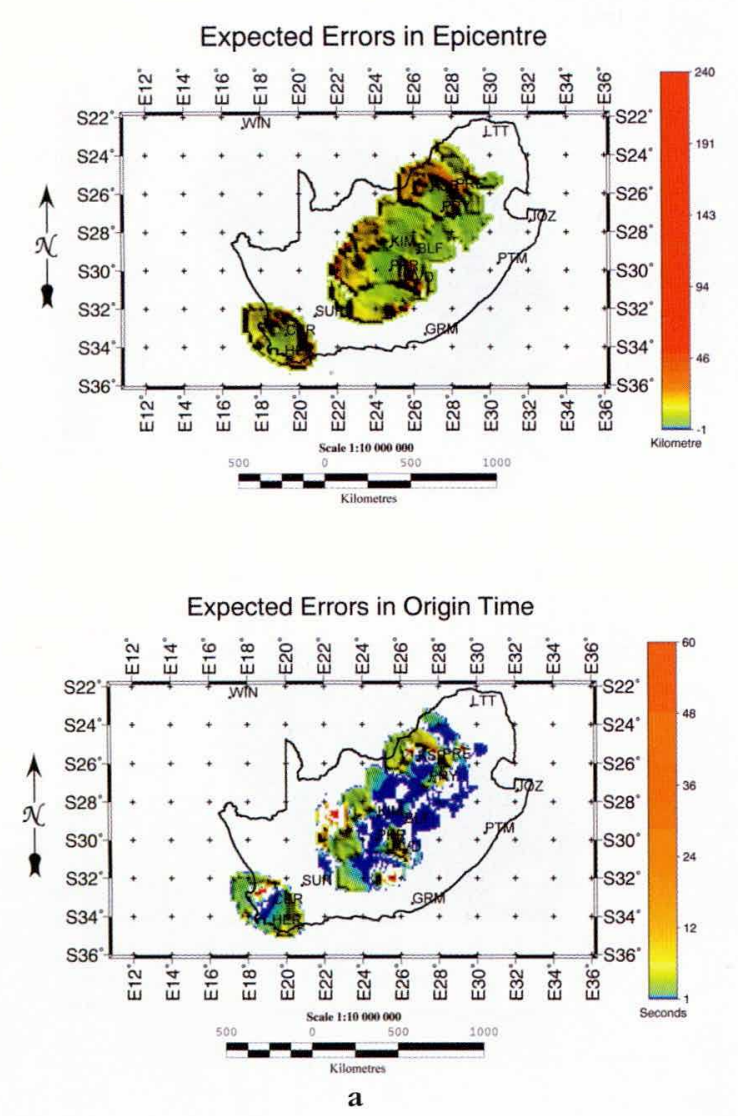

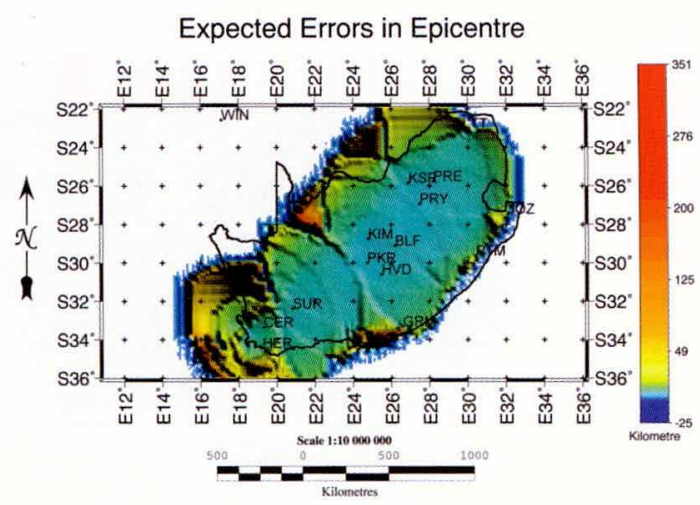

Expected Errors in Origin Time

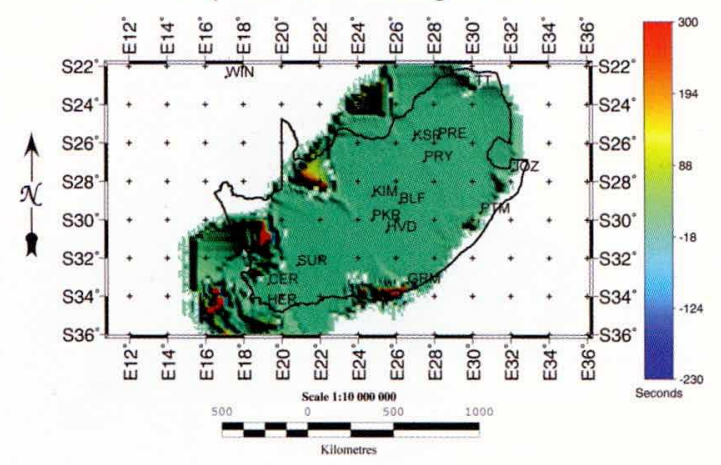

b
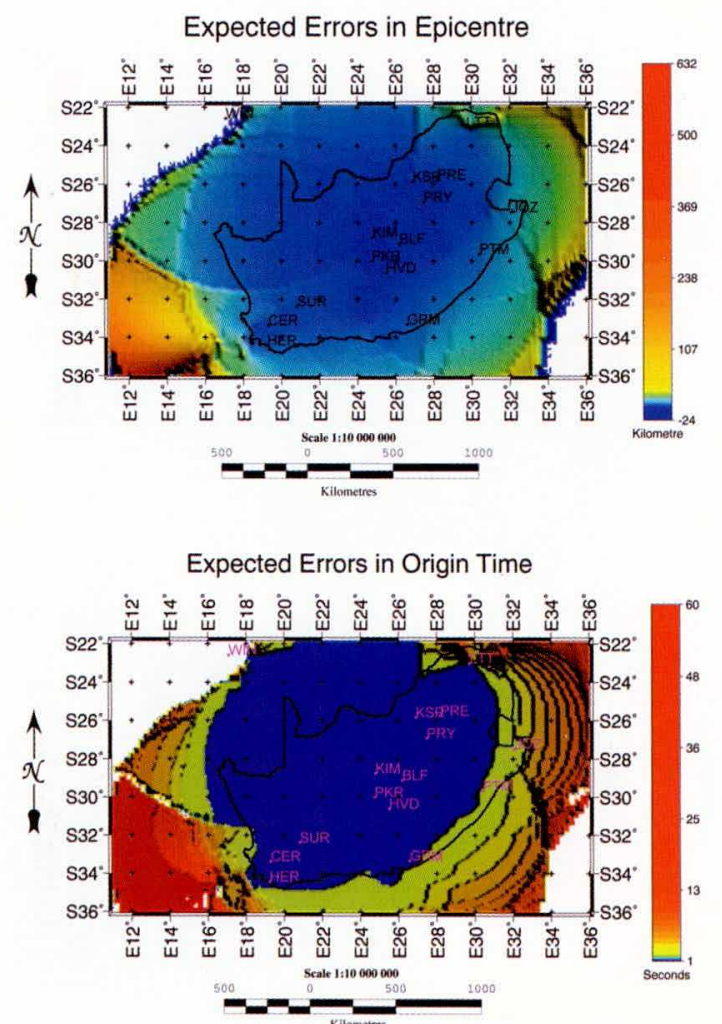

Figure 6. Detection thresholds obtained with the Wright et al. (2002) velocity model with a detection distance threshold of: (a) $300 \mathrm{~km}$, (b) $500 \mathrm{~km}$ and, (c) $1000 \mathrm{~km}$. The calculations were determined with the 1970 station configuration with hypocentral depth of $5 \mathrm{~km}$ considering P-wave arrival times. 

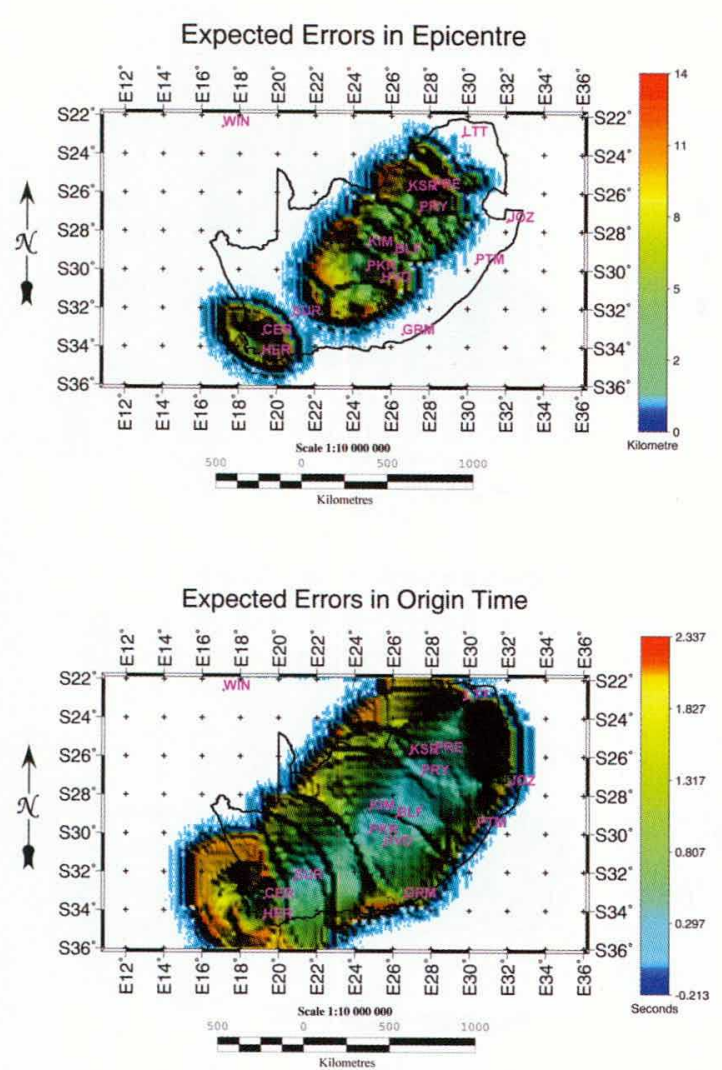

a
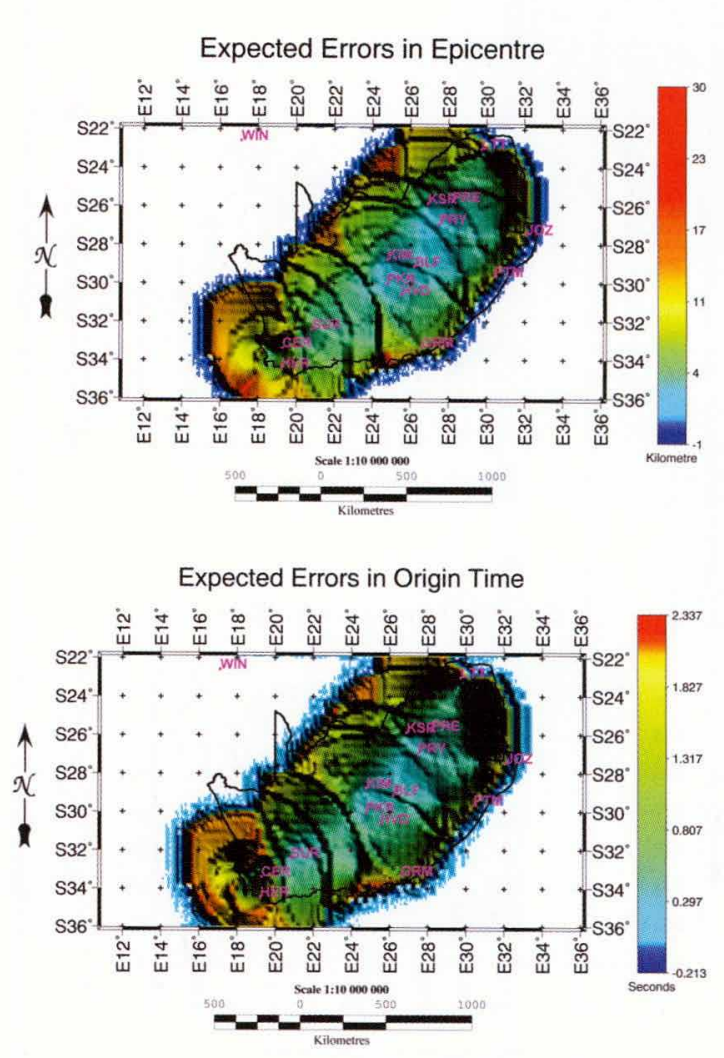

b
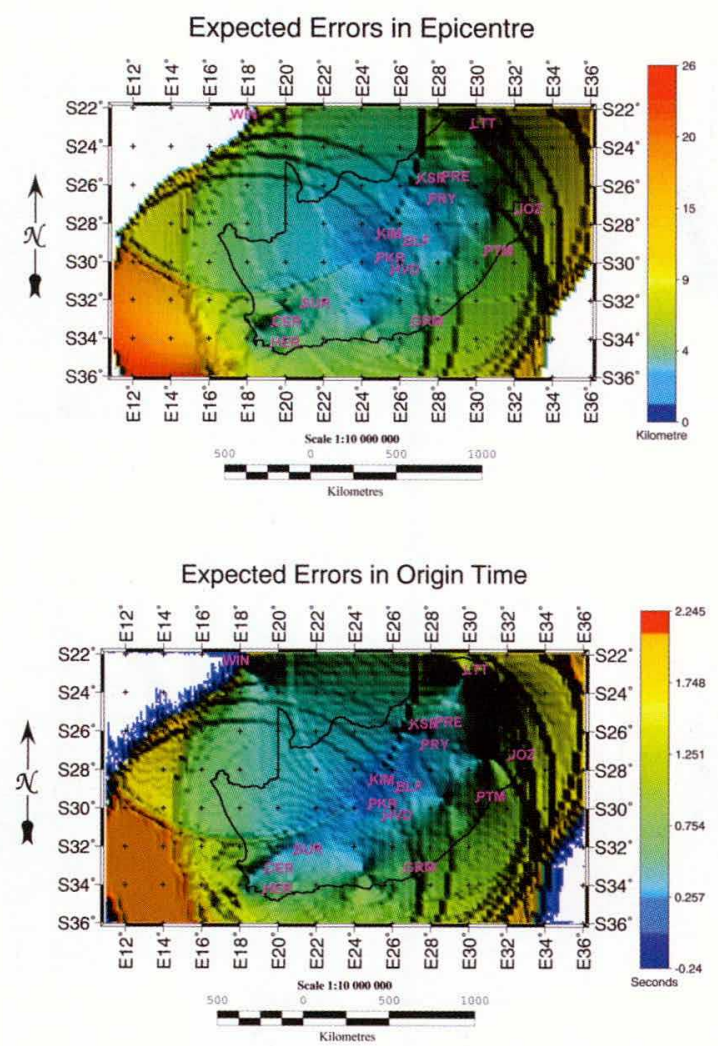

c

Figure 7. Detection thresholds obtained with the Wright et al. (2002) velocity model with a detection distance threshold of: (a) $300 \mathrm{~km}$, (b) $500 \mathrm{~km}$ and (c) $1000 \mathrm{~km}$. The calculations were determined with the 1970 station configuration with hypocentral depth of $5 \mathrm{~km}$ considering $P$ - and S-wave arrival times. 
Expected Errors in Epicentre

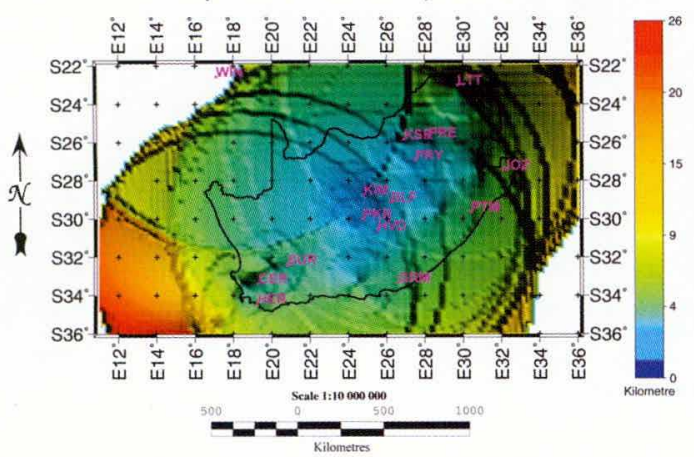

Expected Errors in Origin Time

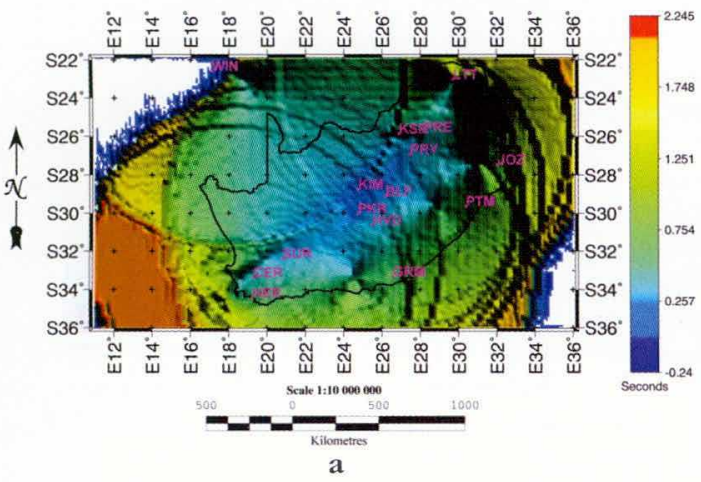

Expected Errors in Epicentre

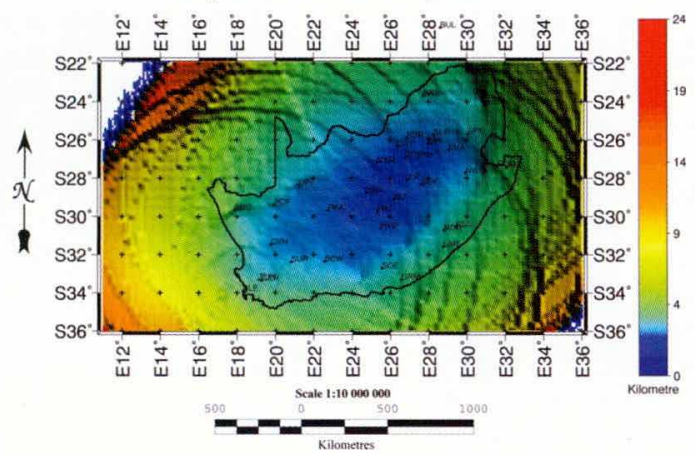

Expected Errors in Origin Time

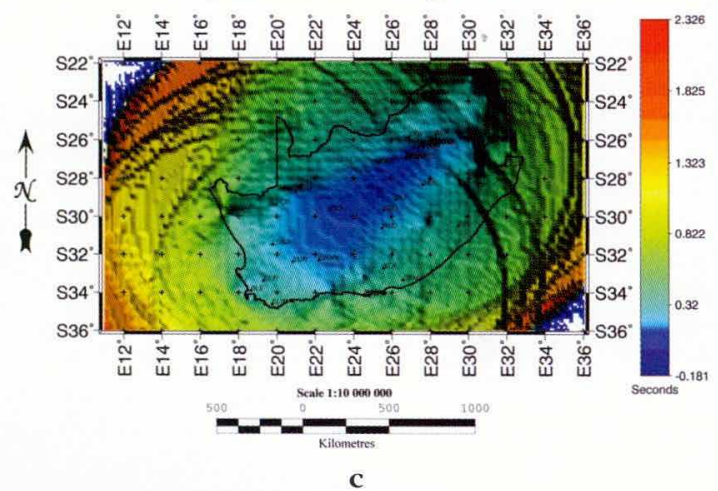

Expected Errors in Epicentre

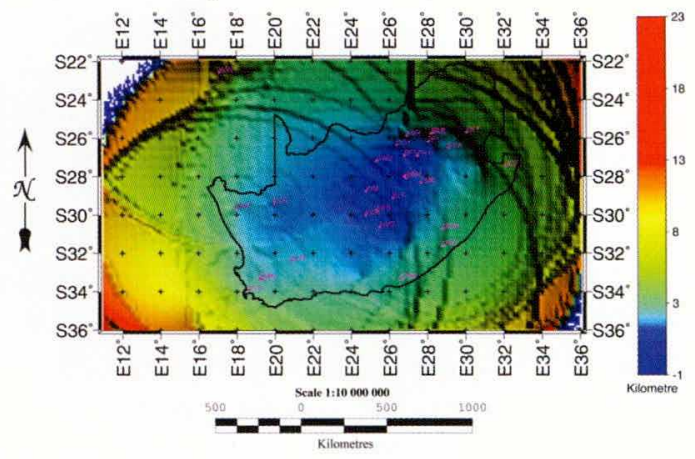

Expected Errors in Origin Time

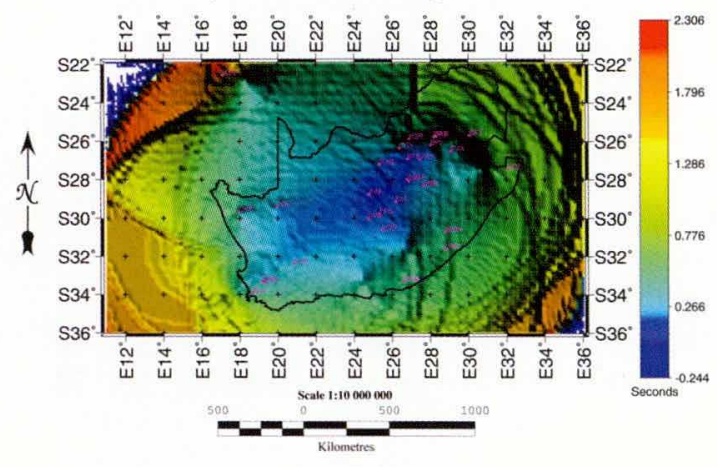

b

Expected Errors in Epicentre

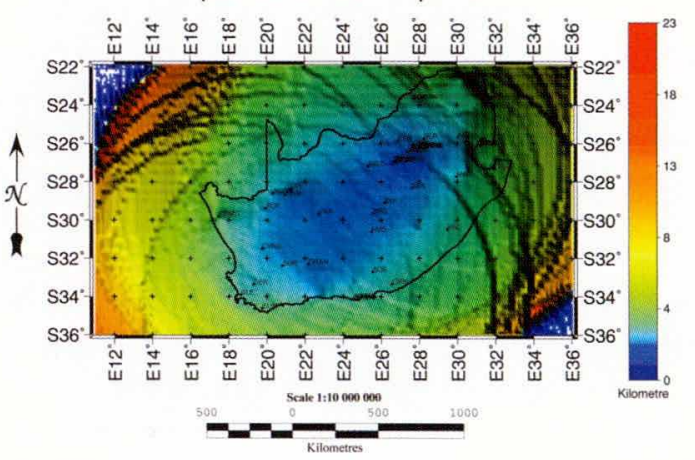

Expected Errors in Origin Time

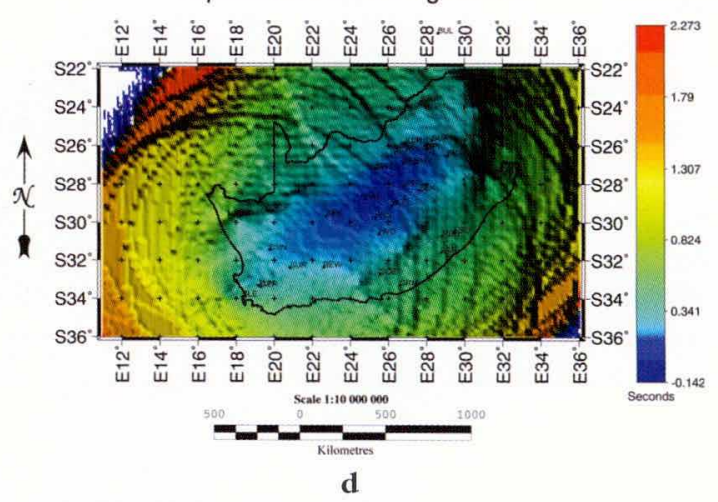

Figure 8. Detection thresholds obtained with the Wright et al. (2002) velocity model with a detection distance threshold of: $1000 \mathrm{~km}$ with the (a) 1970 configuration, (b) the 1980 configuration, (c) the 1990 configuration and (d) the 2000 configuration. The calculations were determined for a hypocentral depth of $5 \mathrm{~km}$ considering $P$ - and S-wave arrival times. 
The effect of varying hypocentral depths is shown as Figure 5 (a to c). The figures attest to subtle changes in the expected epicentre errors to the north of the SANSN, and also a slight variation in the expected error in origin time to the south. This behavior, hypocentral depth having little effect on the expected location capability, is expected since the travel time derivative changes slowly with hypocentral depth (e.g. Havskov and Ottemöller, 2010).

Similarly, Figure 6 (a to c) demonstrates the effect of three arbitrarily selected detection thresholds; 300,500 and $1000 \mathrm{~km}$. Significant differences in the location capability of the SANSN are noticed by varying the detection distance. This is understandable considering the sparse station distribution of the SANSN during the 1970 to 1979 period when large gaps existed between the denser station concentration in the north (gold mining areas), and the concentration of stations around the Ceres area. A noticeable feature is the elongated northeast-southwest pattern accentuated in (Figure 6a) which highlights the bias in the azimuthal distributions of stations. The pattern is repeated in (Figure 6b) $(500 \mathrm{~km}$ detection distance), but is not obvious when considering a detection distance of $1000 \mathrm{~km}$ (Figure 6c) where the influence of the WIN station in Namibia is clearly emphasized.

The importance of including S-phase arrivals in the statistical location capability of the SANSN is highlighted in Figure 7 (a to c). It is evident that a noticeable improvement in both the expected error in location (epicentre and origin time) is achieved when comparing (Figures $6 \mathrm{a}$ and $7 \mathrm{a}$ ). The maximum expected error in origin time decreases from $5.0 \mathrm{sec}$ to $2.1 \mathrm{sec}$ (Figures $6 \mathrm{a}$ and $7 \mathrm{~b}$ ). This trend is maintained for both the $500 \mathrm{~km}$ distance threshold (Figures $6 \mathrm{~b}$ and $7 \mathrm{~b}$ ) and $1000 \mathrm{~km}$ distance threshold (Figures $6 \mathrm{c}$ and $7 \mathrm{c}$ ).

Figures 8 (a to d) conclude the study and indicate the statistical capability of the SANSN during the decades 1970 to 1979, 1980 to 1989,1990 to 1999 and 2000 to 2014. We used the optimum scenario by considering a detection threshold of with both P- and S-phase arrivals in all instances. It is intuitive that the expected errors in location decrease with each decade as the SANSN station coverage expanded. However, it is also evident that the omission of the station during 1990 led to an increase of location errors in the west and north of the study area.

\section{Conclusion}

This study reviewed the potential detection capability and location accuracy of the SANSN during the time period 1970 to 2014. The effect of varying parameters such as the velocity model, hypocentral depth, detection distance and phasearrivals was investigated. This study provides valuable insight into the expected location errors of the SANSN. It is further evident that development and cooperation of seismic networks within South Africa and neighboring countries can benefit the communities within southern Africa.

As a closing statement, it is recommended that a supplementary study be undertaken to evaluate the detection capability of the SANSN from empirical arrival time residuals during a similar period.

\section{Acknowledgements}

This work was funded through the South African National Seismograph Network operated by the Geophysics Competency of the Council for Geoscience. The authors wish to extend their gratitude to Lindsay Lindzer and an anonymous reviewer, whose input as referees much improved the article. The authors further thank the copy editor, Sonja van Eck, for her meticulous and careful review of the manuscript. This is Inkaba ye Africa contribution number 136 and the African Earth Observatory Network (AEON) contribution number 147.

\section{References}

Akromah, L., 2013. Earthquake relocation using the double difference method in the Augrabies area, Report No. 2013-0122, Council for Geoscience, South Africa, 28pp.

Billings, S.D., Sambridge, M.S. and Kennet, B.L.N., 1994. Errors in hypocenter location picking model, and magnitude dependence, Bulletin of the Seismological Society of America, 84, 1978-1990.

Bormann, P., 2002. IASPEI New Manual of Seismological Observatory Practice, P. Bormann (Ed.), published by the GeoForschungsZentrum, Potsdam, Germany, 1253pp. Available at http://nmsop.gfz-potsdam.de.

Box, G.E.P. and Draper N.R., 1975. Robust designs, Biometrika, 62, 347-352. Brandt, M.B.C., 1997. Implementation of SEISAN earthquake software for the SUN to analyze the data obtained through the South African National Seismograph Network, Report No. 1997-0263, Council for Geoscience, South Africa, 48pp.

Brandt, M.B.C., Bejaichund, M., Kgaswane, E.M., Hattingh E. and Roblin D.L., 2005. Seismic history of Southern Africa, Seismological Series 37, Council for Geoscience, South Africa, 32pp.

Brandt, M.B.C. and Saunders I., 2011. New regional Moment Tensor Solutions for South Africa, Seismological Research Letters, 82, 69-80.

Brandt, M.B.C. 2014. Focal depths of South African earthquakes and mine events, Journal of the Southern African Institute of Mining and Metallurgy, $114,855-862$.

Braun, J., Guillocheau, F., Robin, C., Baby, G. and Jelsma, H., 2014. Rapid erosion of the Southern African Plateau as it climbs over a mantle superswell, Journal of Geophysical Research: Solid Earth, 119, 6093-6112.

Carlson, R.W., Grove, T.L., de Wit, M.J. and Gurney, J.J., 1996. Program to study crust and mantle of the Archean craton in southern Africa, EOS, Transactions of the American Geophysical Union, 77 (29), 273-277.

Douglas, A., Bowers, D. and Young, J.B., 1997. On the onset of P seismograms, Geophysical Journal International, 129, 681-690.

Douglas, A., Young, J.B., Bowers, D. and Marshall, P.D., 2005. An analysis of $\mathrm{P}$ travel times for Nevada Test Site explosions recorded at regional distances, Bulletin of the Seismological Society of America 95, 941-950.

Diehl, T., Kiesling, E. and Bormann, P., 2011. Tutorial for consistent phase picking at local to regional distances. Information sheet IS 11.4 in IASPEI New Manual of Seismological Observatory Practice, Vol. 2, P. Bormann (Editor), published by the GeoForschungsZentrum, Potsdam, Germany, 21 pp. Available at http://nmsop.gfz-potsdam.de.

Du Plessis, A., 1996. Seismicity in South Africa and its relationship to the geology of the region, Report No. 1996-0019, Council for Geoscience, South Africa, 13pp.

Fernández, L.M., 1973. Program to evaluate epicentral distance, origin time and local magnitude of regional tremors, Report No. Gh 1968, Geological Survey of South Africa, 11pp.

Fernández, L.M. and Guzmán, J.A., 1979. Seismic history of Southern Africa, Seismological Series 9, Geological Survey of South Africa, 38pp.

Fernández, L.M., 1987. Users guide for a package of programs to locate and evaluate seismic events, Report No. 1987-0128, Council for Geoscience, South Africa, 53pp.

Fernández, L.M., 1991. A UNIX operating software package to process the data obtained by the South African National Digital Seismological System, Report No. 1991-0009, Council for Geoscience, South Africa, 25pp. 
Fernández, L.M., Otto, M.A. and Steyn, J., 1991. The South African National Digital Seismological System (SANDSS), a dial-up telephone-linked network, Tectonophysics, 209 (1-4), 35-43.

Fernández, L.M., 1996. Seismological processor: A computer program in HP-BASIC/UX to process the data of the South African National Digital Seismological System (SANDSS), Report No. 1996-0319, Council for Geoscience, South Africa, 25pp.

Flinn, E.A., 1965 Confidenee region and error determinations for seismic event location, Reviews of Geophysics, 3, 157-185.

Gane, P.G., 1946. A seismic investigation of the Witwatersrand earth tremors, Bulletin of the Seismological Society of America, 36, 49-80.

Gane, P.G., Atkins, A.R., Sellschop, J.P.F. and Seligman, P., (1956). Crustal structure of the Transvaal, Bulletin of the Seismological Society of America, 46, 293-316.

Ge, M., 2003. Analysis of source location algorithms: Part II. Iterative methods, Journal of Acoustic Emission, 21, 29-51.

Gibowicz, S.J. and Kijko, A., 1994. An Introduction to Mining Seismology, Academic Press, San Diego, 1994, 403pp

Goldbach, O.D. 2009. Seismic risks posed by mine flooding, Southern African Institute of Mining and Metallurgy, Hard Rock Safe Safety Conference, South Africa, 28-30 September 2009, 149-174

Gomberg, J.S., Shedlock, K.M. and Roecker, S.W., 1990. The effect of S-wave arrival times on the accuracy of hypocenter estimation, Bulletin of the Seismological Society of America, 80 (6), 1605-1628.

Green, R.W.E. and Bloch S., 1971. The Ceres, South Africa, earthquake of: Report on some aftershocks, Bulletin of the Seismological Society of America, 61 (4), 851-859.

Graham, G., Crampin, S. and Fernández, L.M., 1991. Observations of shearwave polarizations from rockbursts in a South African gold field: an analysis of acceleration and velocity recordings, Geophysics Journal International, 107, 661-672.

Guzmán, J.A., 1977. Evaluation of tables of epicentral distances and P-wave travel times as a function of (S-P) time travel, Report No. Gh 2298 , Geological Survey of South Africa, 19pp.

Guzmán, J.A., 1978. A package of computer programs for the evaluation of local earthquakes and publication of the seismological bulletin, Report No. Gh 2446, Geological Survey of South Africa, 38pp.

Havskov, J. and Ottemöller, L., 2010. Routine earthquake analysis in earthquake seismology: With sample data, exercise and software. Chapter 5, Springer, ISBN 978-90-481-8696-9.

Husen, S. and Hardebeck, J.L., 2010. Earthquake location accuracy, Community Online Resource for Statistical Seismicity Analysis, doi: 10.5078/corssa-55815573, Available at http://www.corssa.org.

Hutton, K., Woessner, J. and Hauksson, E., 2010. Earthquake Monitoring in Southern California for Seventy-Seven Years (1932-008), Bulletin of the Seismological Society of America, 100, 423-446.

Johnston, A.C., Coppersmith, K.J., Kanter, L.R. and Cornell, C.A., 1994 The earthquakes of stable continental regions, Electric Power Research Institute Report, TR-102261-V1, Palo Alto, California, 215pp.

Kijko, A., 1977a. Algorithm for optimum distribution of a regional seismic network 1, Pure and Applied Geophysics, 115, 999-1009.

Kijko, A., 1977b. Algorithm for optimum distribution of a regional seismic network 2. Analysis of accuracy of location of local earthquakes depending on number of seismic stations, Pure and Applied Geophysics, 115, 1011-1021.

Kijko, A., 1978. Methods of the optimal planning of regional seismic networks, Publication of the Institute of Geophysics, Polish Academy of Science, A-7 (119), 63pp

Kijko, A. and Sellevoll, M.A., 1982. A statistical-model for estimating the accuracy of event location applied to a network of Scandinavian stations Pure and Applied Geophysics, 120, 186-196.

Kijko, A. and Sciocatti, M., 1995. Optimum spatial distribution of seismic stations in mines, International Journal of Rock Mechanics and Mining Sciences, 32, 607-615

Kijko, A., 1997. Keynote lecture: Seismic hazard assessment in mines, In: S. J. Gibowicz and S. Lasocki (Editors), Rockbursts, Proceedings of the 4th International Symposium on Rockbursts and Seismicity in Mines, Krakow, Poland, 11-14 August, 1997, A.A. Balkema, Rotterdam, The Netherlands, 247-256.

Klose, C.D. and Seeber, L., 2007. Shallow seismicity in stable continental regions, Seismological Research Letters, 78, 554-562.

Lay, T. and Wallace, T.C., 1995. Modern Global Seismology, Academic Press, San Diego, U.S.A., 521pp

Lienert, B.R.E. and Havskov J., 1995. A computer program for locating earthquakes both locally and globally, Seismological Research Letters, $66(5), 26-36$.

Lomnitz, C., 1977. A fast epicenter location program, Bulletin of the Seismological Society of America, 67, 425-431.

Matuludi, M.J., 2013. Interpretation of the seismicity of Leeu-Gamka Cluster, Western Cape: April 2006 to June 2011, Unpublished B. Tech Dissertation, Tshwane University of Technology, South Africa, 70pp.

McGarr, A., 1976. Seismic moments and volume changes, Journal of Geophysical Research, 81, 1487-1494

Midzi, V., Saunders, I., Brandt, M.B.C. and Molea, T.T., 2010. 1-D velocity model for use by the SANSN in earthquake location, Seismological Research Letters, 81, 460-466.

Nyblade, A.A. and Sleep, N.H., 2003. Long lasting epeirogenic uplift from mantle plumes and the origin of the Southern African Plateau, Geochemistry, Geophysics, Geosystems, 4, (12), 1105, doi:10.1029/2003GC000573.

Ottemöller, L., Voss, P. and Havskov J., 2013. The SEISAN Earthquake Analysis Software for the Windows, Solaris, Linux and MACOSX. University of Bergen. Bergen. Norway, 402pp.

Pavlis, G.L., 1986. Appraising earthquake hypocenter locations - a complete, practical approach for single-event locations, Bulletin of the Seismological Society of America, 76 (6), 1699-1717.

Rabinowitz, N. and Steinberg, D.M., 2000. A statistical outlook on the problem of seismic network configurations, Chapter 3 in Advances in Seismic Event Locations, C.H. Thurber and N. Rabinowitz (Editors), Kluwer Academic Publishers, Dordrecht/Boston/London, ISBN 0-79236392-2, 271pp.

Saunders, I., 1996. Seismological Bulletin for April 1996, Lesotho Highlands Development Authority, 20pp

Saunders, I., Buso, L. and Sutherland, B.E., 2006. Study to evaluate and implement a new velocity model for locating earthquakes recorded by the South African National Seismograph Network (SANSN), Report No. 2006-0058, Council for Geoscience, South Africa, 16pp.

Saunders, I., Brandt, M.B.C., Steyn, J., Roblin, D.L. and Kijko A., 2008. The South African National Seismograph Network, Seismological Research Letters, 79, 203-210.

Saunders. I. and Roblin, D.L., 2008. Catalogue of earthquakes in Southern Africa and surrounding oceans for 2005, Seismological Series No. 41 Council for Geoscience, South Africa, 39pp.

Shapira, A., Fernández, L.M. and Du Plessis, A., 1987. On certain aspects of the seismicity of southern Africa, Report No. 1987-107, Geological Survey of South Africa, 11pp.

Singh, M., Kijko, A., and Durrheim, D., 2009. Seismotectonic models for South Africa: Synthesis of geoscientific information, problems and the way forward, Seismological Research Letters, 80, 71-80.

Smit, L., Fagereng, A., Braeue,r B. and Stankiewicz, J., 2015. Microseismic activity and basement controls on an active intraplate strike-slip fault, Ceres-Tulbagh, South Africa, Bulletin of the Seismological Society of America, 105, 1540-1547.

South African Mineral Deposits Database (SAMINDABA), 2014. Council for Geoscience, South Africa http://www.geoscience.org.za/samindaba

Steinberg, D., Rabinowitz, M, N., Shimshoni, Y. and Mizraehi, D., 1995. Configuring a seismographic network for optimal monitoring of fault lines and multiple sources, Bulletin of the Seismological Society of America, $85,1847-1857$

Trnkoczy, A., Havskov, J., and Ottemöller, L., 2002. Seismic Networks, Chapter 8, In: IASPEI New Manual of Seismological Observatory Practice, Vol. 1, P. Bormann (Editor), published by the GeoForschungsZentrum, Potsdam, Germany, 59pp. Available at http://nmsop.gfz-potsdam.de

Viola, G., Kounov, A., Andreoli, M.A.G and Matilla, J., 2012. Brittle tectonic evolution along the western margin of South Africa: More than $500 \mathrm{Ma}$ of continued reactivation, Tectonophysics, 514-517, 93-114

Wood, H.E., 1913. On the occurrence of earthquakes in South Africa, Bulletin of the Seismological Society of America, 3, 113-120.

Wright, C., Kwadiba, M.T.O., Kgaswane, E.M. and Simon, R.E., (2002) The structure of the crust and upper mantle to depths of $320 \mathrm{~km}$ beneath 
the Kaapvaal Craton, from P-wave arrivals generated by regional earthquakes and mining-induced tremors, Journal of African Earth Sciences, 35, 477-488.

Wright, C. and Fernández L.M., 2003. Chapter 79, "South Africa", In: H.K. Lee (Editor), International Handbook of Earthquake and Engineering Seismology, Elsevier, The Netherlands, 994pp.
Yamashita, T., 1998. Simulation of seismicity due to fluid migration in a fault zone, Geophysical Journal International, 132, 674-6

Editorial handling: M.J. de Wit and P. Booth, 
Copyright of South African Journal of Geology is the property of Geological Society of South Africa and its content may not be copied or emailed to multiple sites or posted to a listserv without the copyright holder's express written permission. However, users may print, download, or email articles for individual use. 